\title{
Relationships among Sensory Analysis, Isoflavone and Hexanal Contents of Soymilk Powder
}

\author{
Josemeyre Bonifácio da Silva ${ }^{1 *}$, Ilana Felberg ${ }^{2}$, Mercedes Concórdia Carrão-Panizzi $^{3}$, Soo \\ Young Lee $^{4}$ and Sandra Helena Prudencio ${ }^{1}$ \\ ${ }^{I}$ Departamento de Ciência dos Alimentos; Universidade de Londrina; Londrina - PR - Brasil. ${ }^{2}$ Centro Nacional de \\ Pesquisa de Alimentos; Empresa Brasileira de Pesquisa Agropecuária; Rio de Janeiro - RJ - Brasil. Centro \\ Nacional de Pesquisa de Soja; Empresa Brasileira de Pesquisa Agropecuária; Londrina - PR - Brasil. ${ }^{4}$ University \\ of Illinois, Urbana - Champaign; Department of Food Science and Human Nutrition; Urbana - Champaign; IL - \\ USA.
}

\begin{abstract}
The objective of this work was to study the sensory attributes and their relationships with isoflavones and hexanal contents of soymilks made in laboratory and commercial samples. The laboratory soymilk samples showed cooked grain and cotton candy aroma and cooked grain, malty and sweetness flavor (a mild flavor). The commercial samples presented stronger roasted soy, rancid, sesame seeds and fishy aroma and roasted soy, sesame seeds and bitterness flavor, and bitter taste (closed nose) and starchy texture. No differences were noted among laboratory soymilks, denoting inactivation of lipoxygenases enzymes in the soymilks process. There were differences between the samples prepared in laboratory and commercial soymilks, which was due to several factors related to processing techniques. The hexanal average content was positively associated with the cooked grain aroma and isoflavones was positively associated with the cooked grain and cotton candy aroma, cooked grain, malty and sweetness flavor and starchy texture.
\end{abstract}

Key words: quantitative descriptive analysis, hexanal, lipoxygenases, vegetable type soybean, isoflavones

\section{INTRODUCTION}

Despite its excellent nutritive value, soybean grains have not been accepted in many western countries due to its undesirable flavors and tastes characteristics. The undesirable flavors are caused by lipoxygenases enzymes (Axerold et al., 1981) or by autooxidation lipids (Macleod and Ames, 1988). The lipoxygenases isoenzymes catalyze the hydroperoxidation of polyunsaturated fatty acids, mainly linoleic and linolenic acids, forming a variety of volatiles compounds (Liu, 1997). Wolf and Cowan (1975) observed that n-hexanal was the major compound in soybeans and described as possessing beany and rancid flavors. The astringency and bitter taste characteristics are due to the isoflavones and the saponins, respectively (Okubo et al., 1992). Several technological processes have been used to improve these sensory characteristics, but soybean cultivars obtained through genetic breeding allow more economic direct utilization. The processing of soybean grains

*Author for correspondence: josibonifacio@uel.br 
can cause the insolubilization of the protein and result other flavors like toasted or cooked (Liu, 1997). Torres-Penaranda et al. (1998) worked with soymilk and tofu made from lipoxygenases-free and normal soybeans and concluded that there was a reduction in cooked beany flavor and aroma of products made with soybeans lacking lipoxygenases. According to Masuda (1991), different soybean genotypes show specific flavors. For example, vegetable type soybean has sweeter and milder flavor than the normal grain type soybean. Difficulties in describing the sensory attributes of soybean and its products can result a variety of terms used, sometimes, erroneously to explain the undesirable flavors and tastes. Hence, many researchers have adopted the term "beany" but a general descriptor and other specific terms such as green, grassy, painty and bitter have also been used to relate the soybean flavor (Liu, 1997). Torres-Penaranda and Reitmeier (2001) showed that the term "beaniness" involved many complex compounds hence, must be very well defined. To provide a common terminology to describe the soybeans products, N'Kouka et al. (2004) developed a vocabulary of terms to describe the sensory characteristics of soymilks. The objective of this work was to study the sensory attributes and their relantionships with n-hexanal and isoflavones contents of powder soymilks made from lipoxygenase-free, normal and vegetable type Brazilian soybean cultivars and two commercial powder soymilks.

\section{MATERIALS AND METHODS}

\section{Materials and Soymilk processing}

The soybeans cultivars evaluated in this study and used for the preparation of powder soymilk were BRS 213 (lacking lipoxygenases enzymes), BRS 133 normal cultivar and BRM94-52273 vegetable type line. The cultivars were donated by the National Soybean Research Center of the Brazilian Corporation for Agricultural Research - Embrapa. Laboratory powder soymilks processing was conducted according to Felberg et al. (2004) and Cabral et al. (1997). The soybean grains were dehulled and blanched in boiling sodium carbonate solution $(0.25 \%)$ in the ratio $1: 3$ for 20 minutes. After that the grains were ground with boiled water in a warring blender to obtain a suspension with of about $11.5 \%$ of total solids. This suspension was homogenized in an APV Gaulin homogenizer at a pressure of 5000 psi. The end product was formulated with $4.5 \%$ sucrose and homogenized again at the same conditions. The obtained soymilk was spray-dried in Niro Atomizer and packed in aluminium bag. Two commercial powder soymilk made from normal cultivars were purchased at the local supermarket (Londrina, Paraná State, Brazil) and used in the sensory study.

\section{Gas chromatography for soymilks n-hexanal volatile analysis}

Serum bottles $(30 \mathrm{~mL})$ containing $0.5 \mathrm{~g}$ powder soymilk with sodium phosphat buffer $(0.05 \mathrm{M}, \mathrm{pH}$ 7.0), were capped with Teflon-coated rubber stoppers and sealed with aluminum caps. The sample bottles were placed in a stove at $105^{\circ} \mathrm{C}$ for 30 minutes to equilibrate the headspace volatile compound in the bottle. Hexanal analysis was determined by gas chromatography using Hewlett Packard GC (model 6890), with a flame ionization detector and a capillary columm $(30 \mathrm{~m} \times 0.32 \mathrm{~mm}$ i.d., $0.2 \mu \mathrm{m}$ film thicknes) from Supelco (model SP 2340) according Utumi et al. (1998). Approximately $1 \mathrm{~mL}$ headspace from each sample bottle was manually introduced in the GC apparatus using syringe gas-tight (AGS, model 5182-9604). The oven temperature was initially set at $45^{\circ} \mathrm{C}$ and then programmed at $9^{\circ} \mathrm{C} /$ minute to $70^{\circ} \mathrm{C}$ and was held for 5 minutes. The temperatures of injector and flame ionization detector were 150 and $220^{\circ} \mathrm{C}$, respectively and the flow rate of nitrogen was $3.5 \mathrm{~mL} /$ minute. The $\mathrm{n}$ hexanal compound in the sample bottles was quantitatively determined using standard curve of compound and the results were expressed as $\mu \mathrm{L}$ of hexanal $/ \mathrm{mL}$ of sample.

\section{HPLC for soymilks isoflavones analysis}

The isoflavones were extracted from the powder soymilk samples as described by Carrão-Panizzi et al. (2002) and the isoflavones contents were determined according to Berhow (2002) in a HPLC system from Waters 2690, equipped with a photodiode array detector and automatic injector. The column was a $4.6 \mathrm{~mm}$ x $250 \mathrm{~mm}$ reverse phase C-18, ODS (YMC-Pack ODS-AM). The column was equilibrated with $20 \%$ methanol $(0.025 \%$ trifluroacetic acid) and $80 \%$ water $(0.025 \%$ trifluroacetic acid $)$ at a flow rate of $1 \mathrm{~mL}$ per minute. After injection, the column was run for 2 minutes at the initial conditions, then developed with a linear gradient to $100 \%$ methanol $(0.025 \%$ 
trifluroacetic acid) over a period of 50 minutes. The wavelength monitored and used for integration was $260 \mathrm{~nm}$. Isoflavones peaks were identified by their spectra and retention time standard curves were prepared with pure standards of daidzin, glycitin and genistin from Sigma Co. (St. Louis, MO). Molar extinction coefficients obtained from these curves were used to determine the levels of all forms of the isoflavones measured in the samples. The results were expressed as $\mathrm{mg} / 100 \mathrm{mg}$ of sample.

\section{Sensory evaluation}

Nine panelists (five female, four male, age range 18 to 40) were selected through sensory questionnaire, scaling exercise and basic tastes tests, such as astringency intensity and bitterness threshold test (Meilgaard et al., 2003). At the first session, a presentation about the basic procedures of sensory evaluation was given to the judges. Five sessions of one hour each were devoted to soymilks tasting and group discussion to describe the samples characteristics with the help of the vocabulary developed by N'Kouka et al. (2004). After an interactive procedure of generation and selecting references was used to describe the samples, 17 terms related to powder soymilks were obtained. The intensities of references were established by consensus of the group. For sensory analysis, the five samples of powder soymilks were dissolved in potable water $(9 \%)$ and shaken thoroughly then $20 \mathrm{~mL}$ poured into $50 \mathrm{~mL}$ plastic cups covered with lids, coded with 3-digit numbers and served for the judges at room temperature. The reference samples were also served at room temperature in plastic cups (30 or $60 \mathrm{~mL}$ ) and labeled with corresponding sensory attribute. The amount of reference samples was standardized by the panelist by consensus. A randomized completed block design with two replications was used to study the sensory attributes of soymilks. The panelists evaluated all the five samples sequentially in single session and in individual booths under incandescent light at room temperature. For individual evaluation, the judges were instructed to shake the sample well before beginning evaluation and to swallow the samples as they evaluated them. Approximately 15 $\mathrm{mL}$ of soymilk was taken into the mouth for every six characteristics evaluated for aroma, six for flavor, two for taste (with closed nose) and three for texture. To promote the cleanliness of the roof of the mouth, the panelists ate bread after completing a sample, thoroughly rinsed their mouth with potable water and then waited five minutes before beginning the next sample. The sheets with unstructured line scale were used with end word anchors "none" (0) to "extreme" (15). The scorecard contained aroma, flavor, aroma via the back of the mouth (taste with closed nose) and texture. Aroma terms evaluated $(n=6)$ were cooked grain, roasted soy, rancid, fishy, sesame seeds and cotton candy. Flavor $(n=6)$ consisted of roasted soy, cooked grain, sesame seeds, astringency, sweetness and bitterness. Tastes with closed nose $(n=2)$ were astringent and bitter. Starchy, thick and mouth coating were the texture characteristics $(n=3)$.

\section{Statistical analysis}

The analysis of variance (ANOVA) and least significant difference (LSD) test were used to determine the differences among the samples, judges, replications or interactions for each attribute. After the analysis of variance, adjusted F-test was conducted when there was a significant interaction for the judges by the samples to the given attribute. These results were statistically analysed in the SAS program version 8.2 (SAS. Inst. Inc. Cary. N.C. U.S.A.). The correlation analysis was carried out to determine the relationships among the sensory attributes, and the Principal Component Analysis (PCA) was used to identify the redundant terms and determine which terms best described each sample. PCA biplots provided a visual representation and global analysis of which terms to describe the powder soymilks. STATISTICA version 6.0 (StatSoft. Inc. N. C. USA. 2001) was used for these statistical analysis. Relationships between the sensory attributes and chemical analysis were determined using STATISTICA version 6.0 (StatSoft. Inc. N. C. USA. 2001).

\section{RESULTS AND DISCUSSION}

The terminology developed for descriptive analysis of soymilks (N'Kouka et al., 2004) helped the panelists to describe the samples in this study. The results of ANOVA showed that there were differences among the samples for all aroma terms and for all the flavor terms, for the bitter (closed nose) and for thick texture and starchy. The ANOVA also showed the high occurrence of judge by sample interaction. This indicated that the 
panelists did not agree on the soymilk which was highest in certain characteristics. Since this interaction was present, it was necessary to do an adjusted F-test to verify if all the reported sample effects were really significant. The results indicated that the following terms remained significant: roasted soy, rancid, sesame seeds and fishy aroma; roasted soy, sesame seeds, malty and bitterness flavor. The LSD means comparison test was conducted on the significant terms aroma, flavor, taste (closed nose) and texture (Table 1). The results provided ways to distinguish among the different soymilks. No differences were noted between the laboratory soymilks for cooked grain, roasted soy, rancid, cotton candy, sesame seeds and fishy aroma; cooked grain, roasted soy, sesame seeds, malty, bitterness and sweetness flavor which also showed stronger values in the attributes for the cooked grain and cotton candy aroma and cooked grain, malty and sweetness flavor. The soymilks made from cultivars BRS 213 and BRS 133 and vegetable type line BRM9452273 were not different for bitter (closed nose). Hence, these soymilks were characterized in the attribute for cooked grain and cotton candy aroma, cooked grain, malty and sweetness flavor, suggesting mild flavor (Table 1). The commercial soymilks were characterized in the attribute for rancid and fishy aroma suggesting undesirable aroma. The commercial soymilk 2 was different from other soymilks and it was stronger in the attribute for roasted soy and sesame seeds aroma and flavor. The commercial soymilk 1 was the same as the soymilks made from cultivar BRS 213 and vegetable type line BRM94-52273 for thick texture. The commercial soymilk 2 was stronger for starchy texture and no difference was noted between the commercial soymilk 2 and the soymilk made from BRM94-52273 for this attribute. The results showed that no differences were observed among the laboratory soymilks, suggesting that in the preparation of the soymilks the heat treatment with sodium carbonate solution inactivated the lipoxygenases enzymes as described by Ha et al. (1992). King et al. (2001) also described that no difference in the beany flavor was found between the soydrinks made from the normal and lipoxygenases-free. However, there were differences between the soymilks prepared in the laboratory and the commercial soymilks which could be due to several factors including processing techniques, that were unknown for the commercial product. TorresPenaranda et al. (1998) reported that the soymilk made from lipoxygenases-free had less cooked beany aroma, less cooked beany flavor and less astringency as compared to the soymilk made from the normal soybeans.

Table 1 - Ratings and least significant differences values for soymilks aroma, flavor, taste (closed nose) and texture. Ratings based on 15- point scale in which $0=$ none and $15=$ extreme. $\alpha=0.05$.

\begin{tabular}{|c|c|c|c|c|c|c|}
\hline Atributtes & BRS 213 & BRS 133 & BRM9452273 & Commercial 1 & Commercial 2 & LSD \\
\hline \multicolumn{7}{|l|}{ Aroma } \\
\hline Cooked Grain & $6.2 \mathrm{a}$ & $6.4 \mathrm{a}$ & $6.8 \mathrm{a}$ & $4.0 \mathrm{~b}$ & $3.7 \mathrm{~b}$ & 1.5 \\
\hline Roasted Soy & $3.0 \mathrm{c}$ & $2.7 \mathrm{c}$ & $2.7 \mathrm{c}$ & $5.3 b$ & $6.9 \mathrm{a}$ & 1.1 \\
\hline Rancid & $1.5 b$ & $1.4 \mathrm{~b}$ & $1.4 \mathrm{~b}$ & $4.8 \mathrm{a}$ & $5.3 \mathrm{a}$ & 1.0 \\
\hline Cotton Candy & $3.1 \mathrm{a}$ & $3.0 \mathrm{ab}$ & $3.3 \mathrm{a}$ & $2.2 b$ & $0.7 \mathrm{c}$ & 0.8 \\
\hline Sesame Seeds & $1.6 \mathrm{c}$ & $1.7 \mathrm{c}$ & $1.5 \mathrm{c}$ & $4.0 \mathrm{~b}$ & $7.6 \mathrm{a}$ & 1.0 \\
\hline Fishy & $0.8 b$ & $0.7 \mathrm{~b}$ & $0.7 b$ & $4.1 \mathrm{a}$ & $5.0 \mathrm{a}$ & 0.9 \\
\hline \multicolumn{7}{|l|}{ Flavor } \\
\hline Cooked Grain & $5.6 \mathrm{a}$ & $5.7 \mathrm{a}$ & $5.5 \mathrm{a}$ & $5.3 \mathrm{a}$ & $3.7 b$ & 1.2 \\
\hline Roasted Soy & $2.8 \mathrm{c}$ & $2.7 \mathrm{c}$ & $2.8 \mathrm{c}$ & $4.7 b$ & $6.5 \mathrm{a}$ & 1.2 \\
\hline Sesame seeds & $1.4 \mathrm{c}$ & $1.3 \mathrm{c}$ & $1.5 \mathrm{c}$ & $3.7 \mathrm{~b}$ & $6.1 \mathrm{a}$ & 0.8 \\
\hline Malty & $6.5 \mathrm{a}$ & $6.8 \mathrm{a}$ & $6.2 \mathrm{a}$ & $3.9 b$ & $2.3 \mathrm{c}$ & 1.0 \\
\hline Bitterness & $1.8 \mathrm{~b}$ & $1.7 b$ & $2.2 b$ & $5.5 \mathrm{a}$ & $1.3 \mathrm{~b}$ & 1.2 \\
\hline Sweetness & $7.6 \mathrm{a}$ & $7.4 \mathrm{a}$ & $7.3 \mathrm{a}$ & $1.4 \mathrm{~b}$ & $1.3 b$ & 1.2 \\
\hline \multicolumn{7}{|l|}{ Taste (closed nose) } \\
\hline Bitter & $1.5 \mathrm{c}$ & $1.8 \mathrm{c}$ & $2.4 \mathrm{c}$ & $5.4 \mathrm{~b}$ & $6.7 \mathrm{a}$ & 1.2 \\
\hline \multicolumn{7}{|l|}{ Texture } \\
\hline Thick & $5.0 \mathrm{abc}$ & $4.4 b c$ & $5.3 \mathrm{ab}$ & $6.0 \mathrm{a}$ & $4.2 \mathrm{c}$ & 1.1 \\
\hline Starchy & $2.9 \mathrm{~d}$ & $3.9 \mathrm{dc}$ & $5.2 \mathrm{ab}$ & $4.4 \mathrm{bc}$ & $5.9 \mathrm{a}$ & 1.3 \\
\hline
\end{tabular}


Correlation analysis was conducted to determine the relationships among the individual terms (data not shown). High correlations were found among the attributes. Cooked grain aroma was positively correlated with cotton candy aroma, cooked grain and malty flavor. Roasted soy aroma was positively correlated with sesame seeds aroma, rancid aroma, fishy aroma, roasted soy flavor, sesame seeds flavor and bitterness taste, but was negatively correlated with malty flavor. When all the soymilks were subjected to PCA, $91.57 \%$ of the variance was described by the principal components (PC) 1 and 2 (Fig. 1). PC1 explained $80.58 \%$ of the variance and showed that it was composed of cooked grain, roasted soy, rancid, fishy, cotton candy and sesame seeds aroma; cooked grain, roasted soy, sesame seeds, malty, sweetness and bitterness flavor; bitter taste (closed nose) and starchy texture. PC 2 explained $10.99 \%$ of the variance and was described by thick texture. Sensory profile of each sample is presented in Figure 2.

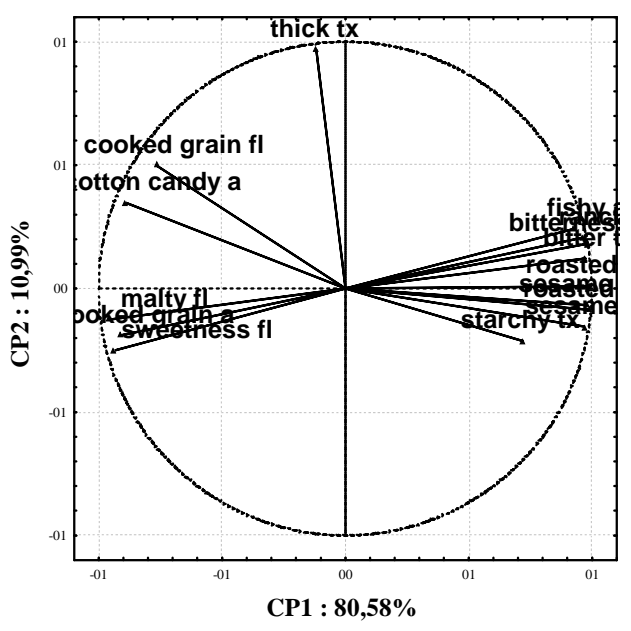

Figure 1 - Principal component analysis plots of CP1 and CP2 of attributes. The acronym (s) next to the attributes indicate the following modalities: $\mathrm{a}=$ aroma; $\mathrm{fl}=$ flavor; $\mathrm{t}=$ taste (closed nose); tx = texture.

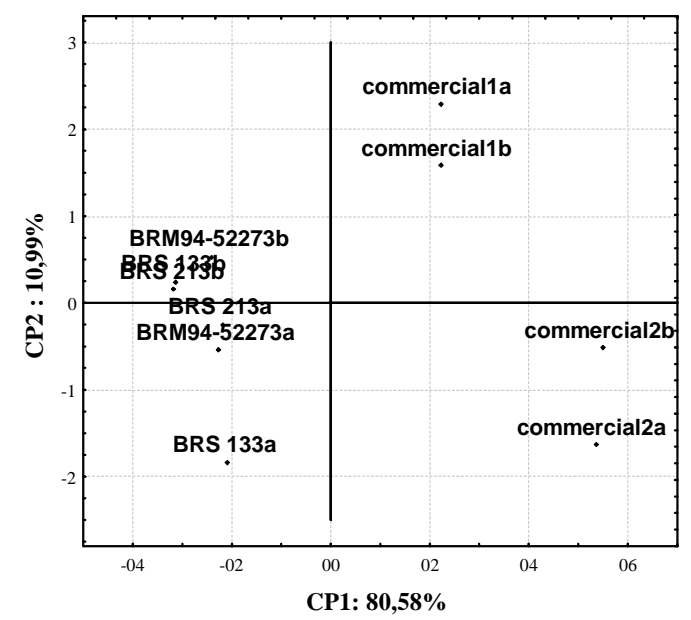

Figure 2 - Principal component analysis plots of CP1 and CP2 of soymilks samples. The letter next to the soymilk samples indicate (a) repetition 1 and (b) repetition 2.

The PCA 1 separated the samples BRS 213, BRS 133 and BRM94 52273 to the left and the samples commercial soymilks to the right, indicating that the soymilks made from laboratory were characterized by the cooked grain and cotton candy aroma; malty, cooked grain and sweetness 
flavor and the commercial soymilks were qualify by roasted soy, rancid, fishy and sesame seeds aroma; roasted soy, sesame seeds and bitterness flavor; bitter taste (closed nose) and starchy texture. The PC2 separated commercial soymilk 1 and commercial soymilk 2. The commercial soymilk 1 showed thicker texture (Fig. 1 and 2). The n-hexanal and isoflavones total average contents of soymilks samples are shown in Table 2. Soymilk made from lipoxygenases-free (BRS 213) had the highest $(181.70 \mathrm{mg} / 100 \mathrm{~g})$ total isoflavones levels and commercial 2 soymilk had the lowest $(91.93 \mathrm{mg} / 100 \mathrm{~g})$. According to Liu (1997), variation in isoflavones contents among soybeans products were influenced by the cultivar and processing method. The hexanal content ranged from $6.20 \mu \mathrm{L} / \mathrm{mL}$ for commercial 2 soymilk to $7.39 \mu \mathrm{L} / \mathrm{mL}$ for soymilk made from vegetable type line (BRM94-52273). In spite of lipoxygenases inactivation, the soymilk made from laboratory showed more concentration of volatile compounds, probably due to lipids autooxidation (Liu, 1997). There has been many studies on the tastes and flavors in soybean and its products and relationships with nonvolatiles and volatile compounds. Wilkens and Lin (1970) concluded that hexanal was the major volatile component in soymilk and the typical green-beany flavor. Min et al. (2005) observed that most of the identified compounds were formed by the lipid oxidation of soymilk and the beany or green flavor that could make the soymilk unpleasant due to 2-pentylfuran formed from linoleic acid by singlet oxygen. Isoflavones and saponins are associated with astringency and bitterness (Okubo et al., 1992).

Table 2 - Isoflavones and n-hexanal total average contents of powder soymilks made from lipoxygenases-free, normal, type vegetable and commercial.

\begin{tabular}{|c|c|c|}
\hline Powder Soymilks & Isoflavones contents $(\mathrm{mg} / \mathbf{1 0 0} \mathrm{g})^{1}$ & n-hexanal contents $(\mu \mathrm{L} / \mathrm{mL})^{1}$ \\
\hline BRS 213 & $181.47 \mathrm{a}$ & $6.34 \mathrm{~b}$ \\
\hline BRS 133 & $160.10 \mathrm{~b}$ & $6.78 \mathrm{ab}$ \\
\hline BRM94-52273 & $143.76 \mathrm{c}$ & $7.39 \mathrm{a}$ \\
\hline Commercial 1 & $118.65 \mathrm{~d}$ & $6.30 \mathrm{~b}$ \\
\hline Commercial 2 & $91.93 \mathrm{e}$ & $6.20 \mathrm{~b}$ \\
\hline C.V $(\%)^{2}$ & 2.71 & 2.78 \\
\hline $\mathrm{SMD}^{3}$ & 3.20 & 0.26 \\
\hline
\end{tabular}

average value of two repetition, means with different letters in the same column are significantly different at $\alpha=0.05$ (Tukey test); ${ }^{2} \mathrm{C} . \mathrm{V}=$ coefficient variation; ${ }^{3} \mathrm{SMD}=$ significance mimimun difference

Table 3 - Correlation among sensory attributes ${ }^{1}, \mathrm{n}$-hexanal and isoflavones contents.

\begin{tabular}{ccc}
\hline Sensory attributes & n-hexanal level & isoflavone level \\
\hline Aroma & $0.76^{*}$ & \\
Cooked Grain & -0.52 & $0.81^{* * *}$ \\
Roasted Soy & -0.60 & $-0.91^{* * *}$ \\
Rancid & -0.52 & $-0.87^{* *}$ \\
Sesame seeds & -0.58 & $-0.87^{* *}$ \\
Fishy & 0.45 & $-0.84^{* *}$ \\
Cotton candy & & $0.79^{* *}$ \\
Flavor & 0.39 & \\
Cooked Grain & -0.55 & $0.74^{*}$ \\
Roasted Soy & -0.55 & $-0.90^{* * *}$ \\
Sesame seeds & 0.47 & $-0.91^{* * *}$ \\
Malty & -0.56 & $0.89^{* * *}$ \\
Bitterness & 0.53 & $-0.92^{* * *}$ \\
Sweetness & & $0.88^{* * *}$ \\
Taste (closed nose) & -0.51 & $-0.96^{* * *}$ \\
Bitter & & \\
Texture & 0.08 & 0.06 \\
Thick & 0.08 & $0.79^{* *}$ \\
Star &
\end{tabular}

$1 * * *, * * *$ Indicates significance at $\mathrm{p}<0.05,0.01,0.001$, respectively $\mathrm{t}$-test (LSD).

2 values of sensory attributes based on $15-$ point scale in which $0=$ none and $15=$ extreme. 
The correlation between the sensory attributes and chemical analysis (Table 3) showed that the hexanal was correlation positively with cooked grain aroma. The isoflavones total content was positively correlated with cooked grain and cotton candy aroma; cooked grain, malty and sweetness flavor and starchy texture and negatively with roasted soy, rancid, sesame seeds and fishy aroma; roasted soy, sesame seeds and bitterness flavor and bitter taste (closed nose).

\section{CONCLUSIONS}

No differences for the attribute of aroma, flavor and taste (closed nose) were noted among the soymilks made from lipoxygenases-free, normal and vegetable type line soybean. This indicated that in the preparation of soymilks, the heat treatment inactivated the lipoxygenases enzymes. The processing without the inactivation could to result sensory differences among the soybean cultivars. The soymilks made in the laboratory showed cooked grain and cotton candy aroma; cooked grain malty and sweetness flavor, suggesting mild flavor. The commercial soymilks showed roasted soy, rancid, sesame seeds and fishy aroma; roasted soy, sesame seeds and bitterness flavor and bitter taste (closed nose) when compared to the soymilks prepared in the laboratory, indicating stronger undesirable soybean flavor. The differences observed were due to several factors related to processing techniques that were unknown for the commercial product but the process used to make the laboratory powder soymilk showed better sensory qualities than the commercial. The hexanal compound was correlated positively with the cooked grain aroma and the isoflavones with cooked grain and cotton candy aroma, cooked grain, sweetness and malty flavor and starchy texture. There is a necessity for more studies about nonvolatiles and volatile compounds and their relationship with the soybean unpleasant flavor and taste.

\section{RESUMO}

O trabalho foi conduzido com o objetivo de descrever os atributos sensoriais de bebidas de extratos de soja em pó produzidos a partir de cultivares desprovida de lipoxigenases, convencional e tipo hortaliça e dois extratos comerciais e correlacioná-los com as quantidades de isoflavonas e n-hexanal nos extratos em pó. Os extratos de soja em pó obtidos em laboratório foram caracterizados pelos atributos: aroma de feijão cozido e de algodão doce; sabor de grão cozido, de malte e gosto doce sugerindo, sabor suave. Os extratos comerciais apresentaram forte aroma de soja tostada, de ranço, de sementes de gergelim e de peixe; sabor de soja tostada, gosto amargo e de sementes de gergelim; gosto amargo (com nariz preso) e consistência de amido. Não foram observadas diferenças sensoriais entre os extratos produzidos em laboratório, indicando a ocorrência da inativação das enzimas lipoxigenases durante $\mathrm{o}$ processamento dos produtos. Contudo, diferenças marcantes entre os extratos obtidos em laboratório e os comerciais quanto aos atributos sensoriais estudados foram encontradas provavelmente, devido às técnicas desconhecidas de processamento utilizadas pelos fabricantes dos produtos comerciais. O teor médio de n-hexanal presente nos extratos de soja comerciais e produzidos em laboratório apresentou correlação positiva e significativa com o atributo aroma de grão cozido, já a quantidade de isoflavonas com aroma de grão cozido e de algodão doce, sabor de grão cozido, de malte, gosto doce e consistência de amido.

\section{REFERENCES}

Axerold, B.; Cheesbrought, T. M.; Laakso, S. (1981), Lipoxygenase from soybean. Methods Enzymological. 71, 441 - 451.

Berhow, M.A. (2002), Modern analytical techniques for flavonoid determination. In: Buslig, B. S.; Manthey, J. A. (ed.). Flavonoids in the living cell. New York: Klusher Academic, p.61-76.

Cabral, L. C.; Wang, SIN H.; Araújo, F. B.; Maia, L. H. (1997), Efeito da pressão de homogeneização nas propriedades funcionais do leite de soja em pó. Revista Ciência e Tecnologia de Alimentos. 17 (3), p. $286-290$.

Carrão-Panizzi, M.C.; Goés Favoni, S.P., Kikuchi, A. (2002), Extraction time for soybean isoflavone determination. Brazilian Archives of Biology and Technology, 45 (4), 515 - 518.

Felberg, I.; Cornejo, F. E. P.; Nascimento, R. E.; Pontes, S. M.; Cabral, L. C. (2004), Obtenção de Extrato de Soja Integral em Pó Formulado com Sacarose. Rio de Janeiro: Embrapa Agroindústria de Alimentos.. Xp. (Embrapa Agroindústria de Alimentos. Comunicado Técnico. 69). No prelo. 
HA, E. Y. W; Morr, C. V.; Seo. (1992), Isoflavone Aglucones and Volatile Organic Compounds in Soybeans; Effect of Soaking Treatments. Journal of Food Science. 57 (2), 414 - 417.

Hartwig, E. E.; Edwards JR, C. J. (1975), Evaluation of soybeans germplasm maturity groups $\mathrm{V}$ to $\mathrm{X}$. Stoneville. Delta Branch Experiment Station. 126 p.

King, J.M; Chin, S.M; Svendsen, L.K; Reitmeier, C.A; Johson, L.A; Ferh, W.R (2001), Processing of Lipoxygenase Free Soybeans and Evaluation in Foods. Journal American Oil Chemistry Society, 78, (4), 353-360.

Liu, K. (1997), Soybeans chemistry technology and utilization. Chapman and Hall. 532p.

Macleod, G.; Ames, J. (1988), Soy flavor and its improvement. CRC Critical Reviews in Food Science and Nutrition. 27 (4), 219 - 401.

Masuda, R. (1991), Quality Requirement and Improvement of Vegetable Soybean. Vegetable Soybean Research Needs for Production and Quality Improvement., p. 92 - 102.

MEILGAARD, M.; Civille, G.V; Carr, B.T. (2003), Sensory evolution techniques. 3rd ed. London: CRC Press, Inc., 387p.

Min, S.; Yu, Y.; Yoo, S.; ST. Martin, S. (2005), Effect of soybean varieties and growing locations on the flavor of soymilk. Journal Food Science, 70 (1), C1C7.

Nelson, A. I.; Steinberg, M. P.; Wei, L. S. (1976), Illinois process for preparation of soymilk. Journal of Food Science. 41 (1), 57 - 61.

N’kouka, K. D.; Klein, B. P.; Lee, S. Y. (2004), Developing a Lexicon for Descriptive Analysis of Soymilk. Journal of Food Science. 69 (7), 213 -217.
Okubo, K.; Ijima, M.; Kobayashi, Y.; Yoshikoshi, M; Uchida, T.; Kudou. S. (1992), Components responsible for the undesirable taste of soybeans seeds. Bioscience Biotechnology Biochemistry. 5, 99 -103 .

Panizzi, M. C. C. (1985), Potencial for narrow leaves in vegetable soybeans. Gainesville. University of Florida. Thesis of Master. 55p.

Stone, H.; Sidel, J. L. (1993), Sensory Evaluation Practices. 2 ed. London: Academic press. Inc.

Torres-Penaranda, A. V.; Reitmeier, C. A.; Wilson, L .A.; Fehr, W. R.; Narvel, J. M. (1998), Sensory Characteristics of Soymilk and Tofu made from Lipoxygenase-Free and Normal Soybeans. Journal Food Science. 63 (6), 1084 - 1087.

Torres-Penaranda, A. V.; Reitmeier, C. A. (2001), Sensory Descriptive Analysis of Soymilk. Journal Food Science. 66 (2), 352 - 356.

Utumi, M.M.; Barros, E.G. de; Oliveira, M.G. de A.; Sediyama, C.S.; Moreira, M.A. (1998), Efeito da eliminação genética de lipoxigenases e de polipeptídios de reserva na qualidade da proteína da soja.,v. Revista Brasileira de Fisiologia Vegetal. 10 (3), 203-212,

Wilkens, W. F.; Lin, F. M. (1970), Gas Chromatografic and Mass Spectral Analyses of Soybean Milk Volatiles. Journal Agricultural Food Chemistry. 18 (3), 333 - 336.

Wolf, W. J.; Cowan, J. C. (1975), Soybean as a food source. Cleveland CRC. 101p.

Received: September 16, 2008; Revised: April 08, 2009; Accepted: April 13, 2010. 